\title{
On the Mismatches between the Monetary and Social Values of Air Purification in the Colombian Andean Region: A Case Study
}

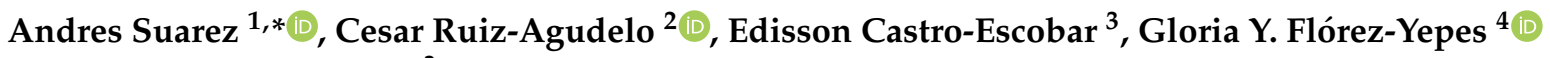 \\ and Luis A. Vargas-Marín ${ }^{3}$ \\ 1 Department of Civil and Environmental, Universidad de la Costa, Calle 58\#55-66, \\ Barranquilla 080001, Colombia \\ 2 Doctoral Program in Environmental Sciences and Sustainability, Universidad Jorge Tadeo Lozano, \\ Bogota 111311, Colombia; cesara.ruiza@utadeo.edu.co \\ 3 Environment and Development Research Center (CIMAD), Universidad de Manizales, Carrera 9a \#19-03 \\ B/Campo Hermoso, Manizales 170001, Colombia; ecastro@umanizales.edu.co (E.C.-E.); \\ lvargas@umanizales.edu.co (L.A.V.-M.) \\ 4 GIDTA Research Group, Universidad Católica de Manizales, Manizales 170001, Colombia; \\ gyflorez@ucm.edu.co \\ * Correspondence: asuarez24@cuc.edu.co
}

\section{check for} updates

Citation: Suarez, A.; Ruiz-Agudelo, C.; Castro-Escobar, E.; Flórez-Yepes, G.Y.; Vargas-Marín, L.A. On the Mismatches between the Monetary and Social Values of Air Purification in the Colombian Andean Region: A Case Study. Forests 2021, 12, 1274. https://doi.org/10.3390/f12091274

Academic Editors:

Elisabetta Salvatori and

Giacomo Pallante

Received: 9 August 2021

Accepted: 15 September 2021

Published: 17 September 2021

Publisher's Note: MDPI stays neutral with regard to jurisdictional claims in published maps and institutional affiliations.

Copyright: (c) 2021 by the authors. Licensee MDPI, Basel, Switzerland. This article is an open access article distributed under the terms and conditions of the Creative Commons Attribution (CC BY) license (https:/ / creativecommons.org/licenses/by/ $4.0 /)$.
Abstract: There is growing interest in air quality and air purification, due to current high pollution levels, their effects on human health, and implications for urban economies. Since the improvement of air quality carries important economic value, air-related benefits have been evaluated monetarily from two perspectives: the first relates to air quality improvements, while the second values air purification as an ecosystem function. This research opted for the second perspective, given that the study area (two Colombian municipalities) does not suffer from poor air quality conditions, but stakeholders prioritized this function as highly important to them. Contingent valuation methods were applied in order to identify the population's probability of willingness to maintain the air purification function. Although individuals $(n=245)$ attribute a yearly monetary value of USD 1.5 million to air purification, it was found that, despite the high level of social importance that respondents assigned to air purification (mean $=4.7 / 5)$, this had no correlation with payment values (rho $=0.0134, p=0.8350$ ); that is, households do not really recognize the monetary value of all the benefits they receive or the benefits they would lose if the service suffers changes. Hence, it is posed that monetary values do not necessarily reflect the social importance that individuals assign to ecosystem services, and attention is called to the need to integrate social and monetary values into decision-making processes, so as to encompass the complexity of ecosystem services and conciliate conflicting valuation language.

Keywords: air purification; deliberation; forest ecosystems; economic valuation; social valuation

\section{Introduction}

It is well known that humankind's well-being relies on different ecosystems and their benefits, on multiple scales, particularly in urban areas. In this regard, ecosystem services (ESs) have gained momentum, as this approach is insightful for decision-making purposes. According to [1], ESs are those ecosystem aspects that lead to human wellbeing. Thus, the generation of ESs begins with the presence of one or more ecosystem structures, which have a variety of ecological functions, and ultimately provide societal benefits [2,3]. As stated by [4], the ecosystem services approach enabled a better understanding of the complexity of human-environmental systems. As stressed by [5], it is necessary to manage ecosystem functions in order to ensure that the composition and structure of ecosystem elements continuously provide well-being for humanity. There are certain ecosystem functions 
that are essential to the maintenance of said well-being, which makes the case for the maintenance of good environmental conditions for these reasons, including air quality, which has received special attention in the past few years [6,7].

Given their role in carbon sequestration, it may be established that forest ecosystems contribute to air purification [8,9]. They are also very important, given their capacity for the absorption of atmospheric contamination [10-13]. The air purification (AP) function provided by vegetation is often quantified as an annual removal of pollutants, mainly on the urban scale [14]. In general, AP has been understood as a human welfare indicator, in terms of air quality or clean air $[15,16]$. AP mainly embodies the production of negative tropospheric ozone, absorption of sulfur dioxide, nitrogen oxides, fluoride, particulate matter (PM10), and noise reduction $[17,18]$. Further, they contribute to a final benefit related to clean-air environments, by removing pollutants from the atmosphere, reducing the cost of human-led air purification, and preventing large expenditures on public health and safety [19].

As the purification of air has important economic values, a common valuation framework has historically been the contingent valuation method [20-23]. Air-related benefits have been evaluated from two perspectives: that related to air quality improvements, and the air purification function, per se, which helps to identify people's willingness to pay (WTP) for air-related processes [24-29]. However, the analysis of the social and monetary values of $\mathrm{AP}$, as a process previous to air quality improvements, has received little attention.

Human decisions and behaviors regarding and toward ecosystems are also determined by the multiple ways in which nature, ecosystems, or ecosystem services are important for individuals or social groups [30-33]. Especially, in the scientific field of ecosystem services, monetary valuation methods have received more attention than other valuation methods [34]. Concentrating only on monetary valuation underscores instrumental values while ignoring both intrinsic and relational values [33]. In recent years, academics that specialize in ecosystem service valuation have adhered to value pluralism: the recognition of different, and often conflicting, value domains that are neither reducible to each other nor to some ultimate value [34-36].

Therefore, this study did not analyze WTP for air quality improvements or strategies aimed at the removal of air pollution from urban areas but instead obtained an ES valuation linked to the surrounding forest ecosystems of two urban areas. These ecosystems promote air quality through their air purification function. The social prioritization of AP supports this valuation, as individuals regard the air purification process as an essential forest function for potential AP, even if there are favorable atmospheric conditions in their areas. In this sense, it is essential to preserve these conditions for the future.

Therefore, the present study aims to contrast the ways in which AP is valued from different perspectives, in order to understand local valuation approach mismatches. To that end, a social and monetary valuation regarding AP, provided by the main ecological structure in two Colombian municipalities, was performed. This main ecological structure consists of those natural and semi-natural areas that promote ecosystem services and are involved in legal Colombian land use planning.

\section{Methods for Monetary Valuation}

Air valuation is a necessary resource for the sustainability of the human species. It does not present a defined market, much less does it present costs for its generation, because this does not depend on human effort. However, the alteration of its structure produces negative effects on humans. Certain valuation methodologies consider value from a cost perspective; thus, "This implies that air pollution (alteration of the minimum levels of acceptance by the human being) must be valued at the cost of correcting the emerging damage" [37], or from other approaches, such as replacement or corrective cost.

Although the choice experiments method has been highlighted as a powerful technique for the prevention of biases and improvement of valuation scenarios, through marginal effects identification, given the complexity of AP and the cognitive burden linked 
to these experiments, this investigation opted to use the contingent valuation (CV) method. Contingent valuation could be used in scenarios in which the generation of ESs could be explained from a broader perspective, rather than the provision of confusing attributes specific to local communities' valuation, particularly for AP. For instance, authors such as [12] call attention to the need to analyze AP through the assessment of pollutant sequestration, specifically $\mathrm{SO}_{2}$ and $\mathrm{NO}_{2}$. Moreover, the authors of [38] suggest approaches such as functional diversity, for pollution absorption. With this in mind, the application of choice experiments could configure incomprehensible attributes for the inhabitants of the municipalities studied herein. In the scientific literature, the combination of match air purification AND choice experiments is scarce. There is a single study, performed in [16], which provides a framework for the application of a choice experiment in AP. However, the investigation was limited to the provision of only those attributes related to increasing area (versus a status quo area). In the context of the present study, this approach was unreliable because the current context of the study area seeks the promotion and conservation of current areas, in order to declare them the main ecological structure.

Therefore, the ES monetary valuation was performed through a contingent valuation method. This method is useful, since it is flexible and could be applicable to many nonmarketed and marketed ESs and allows for the capture of all types of benefits from an ES, including instrumental and non-instrumental values [39]. However, it is known that this method has several weaknesses, such as its high level of sensitivity to survey application, and the potentiality for study biases, which could limit result generalizability [40]. Despite these limitations, contingent valuation has allowed, in different contexts, for the recognition of relationships between the willingness to pay given a population's characteristic, and the opportunity cost of protecting ecologically fragile areas vulnerable to degradation [41].

As defined by [42], the possibility of direct interviews, with contextual explanations of these opportunity costs, permits the limitation of regressive biases and the adverse selection of contingent valuation. The key lies in the contextualization made by researchers about the valuation scenario, such that interviews conducted by indirect means are usually more questioned, as they tend to induce biases and greater response subjectivity [43].

\section{Materials and Methods}

\subsection{Research Area}

This study was carried out in two Colombian municipalities, located in the northern region of the Department of Caldas (Figure 1). These are mainly rural areas and possess less than 31 thousand inhabitants between them (Aguadas $=21,043$, Pácora $=10,608$ ). The current regional landscape has been largely transformed (approximately $20 \%$ of the original ecosystems remain) by human interventions in the last 350 years [44]. Nowadays, a huge portion of the land's surface is used for agriculture, mainly to grow coffee and avocados, raise cattle and grasslands. Said activities have led to the loss of forests. It is noteworthy that only one protected area exists in the above-mentioned zone: the protected "Tarcará", a forest reserve located between the two municipalities under study. In order to manage area ecosystems, the local environmental authority, Corpocaldas, supported the identification, valuation, and projection of the main ecosystems in the zone (main ecological structure), aiming to sustain the generation of ESs for land use planning. In this context, this study was performed to provide information about ES valuation mismatches for local managers, and to subsequently shed light on the need to approach ecosystem management from the perspective of both simplistic (exclusively monetary valuation) and pluralistic valuations.

\subsection{Ecosystem Service Prioritization and Valuation}

A comprehensive approach was proposed to elucidate the values of ESs in the study area. In the present research, this was performed via a two-level analysis-one related to ES deliberative prioritization by stakeholders and an individual-based valuation by way of a survey with a local population sample (valuation of the ESs prioritized). 


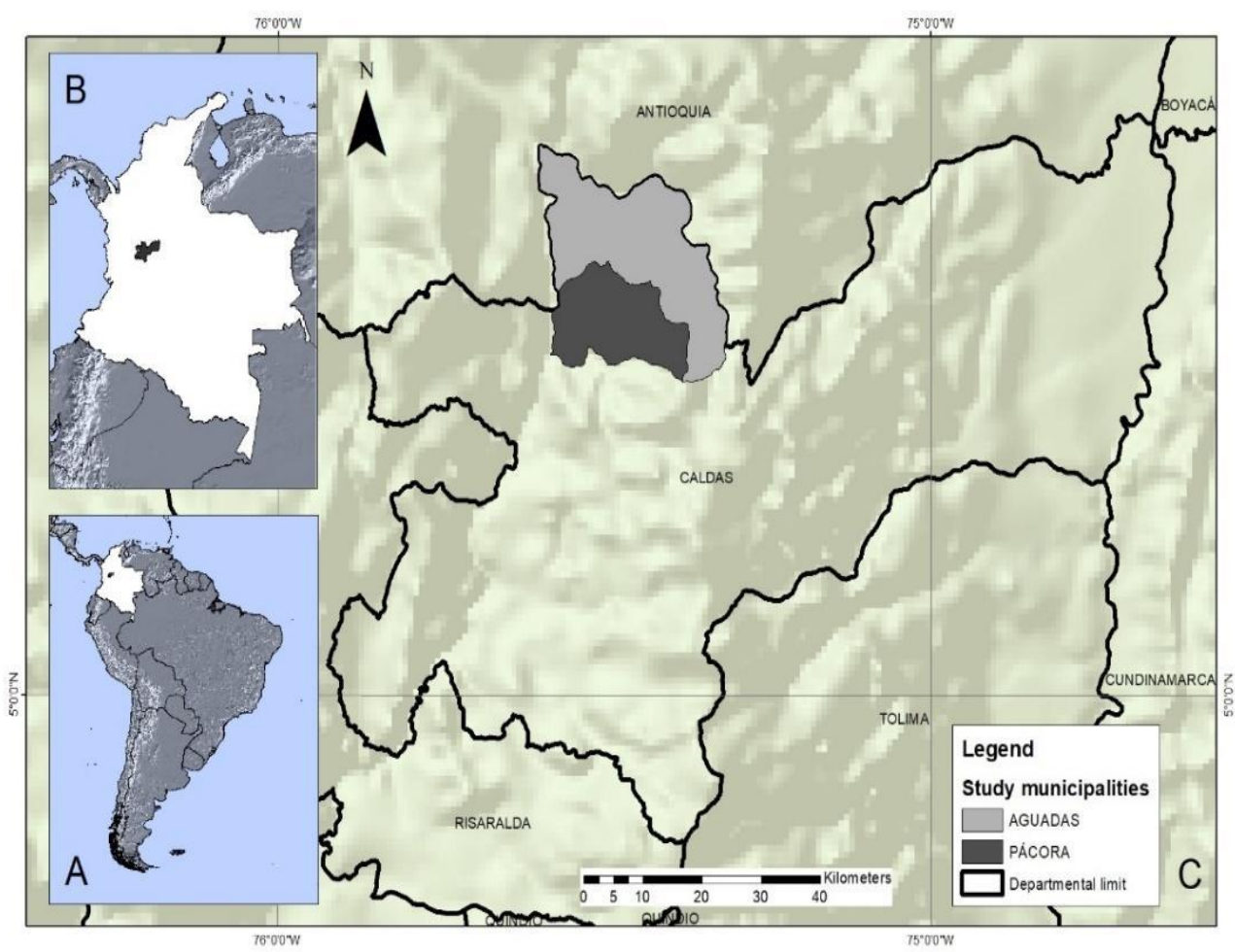

Figure 1. Location of the study area: (A) Latin America; (B) Colombia and Caldas; (C) Aguadas and Pácora.

\subsubsection{Deliberative Prioritization Process}

Two focus groups were convened (one per municipality) to discuss the most important ecosystem services (ESs) for different stakeholders. The recruitment process for the focus group's participants was as follows: first, the local environmental authority provided a list of municipal stakeholders (laypeople, academics, civil servants). Later, calls were made to recruit as many local players as possible to represent different area views. From the municipalities of Aguadas and Pácora, 11 and 26 people participated in the focus groups, respectively, where a deliberative approach to identify ESs (3-4 h discussions, reflections, and deliberation to prioritize ESs) was employed. Researchers provided refreshments, and when needed, attendee transportation expenditures were assumed for some of Pacora's participants.

The sessions occurred in accordance with the steps below:

i. The participants were divided into subgroups to discuss and debate, more extensively, the ESs used and their perceptions thereof.

ii. Researchers provided formats to guide internal discussions. The guide form specified that participants should rank, between 1-5 on the importance scale, those ecosystem benefits that were most important to them, first as individuals, and then as a subgroup (Table S1: Main ecological structure in the two municipalities). In this step of prioritization, participants were encouraged to discuss the most important benefit for them. Additionally, a participatory mapping approach was employed, in which stakeholders were invited to spatialize the priority areas for ES supply. A map of the municipality was provided, with different forest covers. A final guide question was formulated: what kinds of benefits do you receive from the identified municipality's main ecological structure? (Table S2. Ecosystem Services identification and prioritization).

iii. In the plenary session, participants consolidated a list of the most important ESs for their livelihoods (daily life, economic and social development, and ecosystem resilience). The identifications and prioritizations were based on participants' experience and preexisting knowledge of ecosystems in said municipalities and their 
benefits. In both municipalities, air purification (AP) was prioritized as one of the most important benefits provided by forests.

Although each municipality prioritized five ESs, the decision for the selection of air purification for this document was made because it was a common prioritized benefit between the municipalities. Although AP could be considered a function rather than a final ES, stakeholders prioritized AP function as highly important to them, and as a precursor for posterior benefits, including future air quality.

\subsubsection{Contingent Valuation Methodological Process}

A questionnaire was designed to elicit information about socioeconomic characteristics, perceptions about ESs (first prioritized in workshops by stakeholders), and a section relating to their willingness to pay (WTP) for AP was completed (Table 1). The questionnaire underwent an initial adjustment process, through group discussions, with professionals in environmental engineering, biology, and environmental management, as well as with laypeople. The final version of the instrument was built, and in connection with the WTP scenario, an open-ended format was proposed for two reasons: the municipalities' lack of initial reference information with which to generate values and payment ranges, and the current literature that justifies the ratio of open-ended questions in this type of scenario [8,45]. As the elicitation mechanism did not provide a predetermined amount to be paid, all other aspects of the payment were described, such as who pays, the mechanism for said payment, and temporality [46]. A purposive sampling to select sampling points that covered different urban zones was proposed. Urban sampling points encompassed neighborhoods from both Aguadas and Pácora-95\% confidence and 9\% error values were applied.

Table 1. Summary of the contingent valuation methodological process.

\begin{tabular}{|c|c|}
\hline Step & Definition \\
\hline Definition of ES change & $\begin{array}{l}\text { Main ecological structure maintenance to sustain air purification } \\
\text { function. }\end{array}$ \\
\hline $\begin{array}{l}\text { Specification of the contingent valuation model, } \\
\text { definition of variables, indicators, and required data }\end{array}$ & $\begin{array}{l}\text { Definition of binary model WTP }=\text { Yes }(1), W T P=\text { No }(0) \text {. Application of } \\
\text { the Logit model to identify the probability of responding Yes, and Tobit } \\
\text { model to obtain the probability of the maximum value to be paid } \\
\text { (censored model). }\end{array}$ \\
\hline $\begin{array}{l}\text { Specification of the measure for the change in welfare } \\
\text { to be estimated }\end{array}$ & $\begin{array}{l}\mathrm{E}\left(\mathrm{WTP} \mid \mathrm{X}^{\prime} \mathrm{s}\right)=\beta 0+\beta \mathrm{VS}(1) \\
\text { Where } \mathrm{E} \text { is the expected value of the estimated willingness to pay, with } \\
\text { data from the open-ended format, beta parameters are the estimated } \\
\text { regression coefficients, vs. is a vector of socioeconomic variables and } \\
\text { interviewee perception. }\end{array}$ \\
\hline Design of the data collection instrument: survey & $\begin{array}{l}\text { Designing questions about socioeconomic characteristics, perceptions } \\
\text { about the ESs prioritized in the stage of work with stakeholders, and the } \\
\text { section related to the WTP. }\end{array}$ \\
\hline $\begin{array}{l}\text { Sample size calculation and choice of sampling } \\
\text { approach }\end{array}$ & $\begin{array}{l}\text { Simple random sampling with } 95 \% \text { confidence and } 9 \% \text { error. Aguadas } \\
\qquad(N=21,043) \text {, Pácora }(N=10,608) .\end{array}$ \\
\hline Final survey application & Face-to-face meeting in each municipality. \\
\hline Estimation of the econometric model & Logit and Tobit application in Stata $14^{\circledR}$ \\
\hline
\end{tabular}

Given the CV consideration mentioned, in this study, the threats and importance of ecological structure for inhabitants, with assisted questions in an interactive dialogue, were explained to respondents. Additionally, to prevent biases, the ex-post calibration techniques of [47] were followed. For example, researchers (i) emphasized the budgetary consequences of the WTP scenario and respondent choices, (ii) researchers urged respondents to be honest and act as if they had to act at the moment, and (iii) the study sought to reduce the bias of 
social desirability (the tendency to answer that which the interviewee considers socially acceptable) by mentioning some unrealistic examples from previous surveys.

The WTP scenario was as follows: First, trends in the main ecological structure, in both municipalities were explained. These included increases in crop production and growing homogenous land cover (mainly avocado crops) which have led to ecosystem degradation. Later, the study proposed a scenario in which the current main ecological structure was managed, and the local authorities promoted conservation strategies to avoid ecosystem loss and degradation. Finally, the WTP proposed question was "How much would you be willing to voluntarily pay to maintain the current main ecological structure in your municipality and to prevent future degradation"? The question was applied both in Aguadas and Pácora, in accordance with their particularities. Respondents were advised that, in this scenario, by carrying out the necessary conservation actions, they would need to make a monthly payment through utility bills (payments by household). This strategy allowed them to limit payments to within the constraints of household spending.

Regarding the empirical model involved in this exercise, two levels of analysis were used: the application of a Logit model, with marginal effects, by which to identify the determinants in respondents' willingness to pay, whereas the second one was a censored Tobit model (given the zero results for open WTP questions) with marginal effects for the identification of those factors that influenced maximum monetary values that respondents would pay.

Additionally, through the Mann-Whitney U-test, the values stated by respondents in the two municipalities $(p<0.05)$ were tested for differences among these. Models were calculated using the Stata $14^{\circledR}$ software (StataCorp, 4905 Lakeway Drive, College Station, TX, USA).

Finally, the questionnaire inquired about the importance (1-5 scale) that respondents attributed to the AP for monetary valuation purposes. Although WTP usually aimed to translate the random utility of an individual in monetary terms, we intentionally pointed out that although WTP demonstrates social utility, when asking for social perspectives apart from WTP, people assign even greater social values beyond what the payment represents.

Therefore, an open-ended question on the WTP for this ES was applied, and the following hypothesis was proposed to test instrumental and non-instrumental values: there is a significant relationship between social importance and monetary values assigned to the prioritized ES. This hypothesis ought to discover whether the higher the social importance of the ES, would indicate higher values that individuals would be willing to pay. To this end, a Spearman's correlation test $(p<0.05)$ was applied.

\section{Results}

\subsection{Socioeconomic Characteristic of the Respondents}

A total of 245 people, from both municipalities, were sampled. Most respondents were female $(63 \%)$, and fell within the over-40 years-of-age range $(51 \%)$, had middle or low education levels, and were mainly urban residents $(93 \%)$. The respondents stated that they had low-income levels (53\% reported earning less than one minimum Colombian legal wage), and most also stated that they were familiar with the natural ecosystems in their municipalities ( $84 \%$ ). Table 2 shows socioeconomic information by municipality, detailing the frequencies and percentages of the items considered by this study.

Table 2. Respondent socioeconomic information $(n=245)$.

\begin{tabular}{ccccccc}
\hline Municipality & \multicolumn{2}{c}{ Aguadas $(\boldsymbol{n}=\mathbf{1 2 4})$} & \multicolumn{2}{c}{ Pácora $(\boldsymbol{n = 1 2 1})$} & \multicolumn{2}{c}{ Consolidated $(\boldsymbol{n = 2 4 5 )}$} \\
\hline Variable & Frequency & $\mathbf{( \% )}$ & Frequency & $\mathbf{( \% )}$ & Frequency & \% \\
\hline Gender & & & & & & \\
\hline Male & 52 & 42 & 51 & 42 & 103 & 46 \\
Female & 72 & 58 & 70 & 58 & 142 & 63 \\
\hline
\end{tabular}


Table 2. Cont.

\begin{tabular}{|c|c|c|c|c|c|c|}
\hline \multirow{2}{*}{$\begin{array}{c}\text { Municipality } \\
\text { Variable }\end{array}$} & \multicolumn{2}{|c|}{ Aguadas $(n=124)$} & \multicolumn{2}{|c|}{ Pácora $(n=121)$} & \multicolumn{2}{|c|}{ Consolidated $(n=245)$} \\
\hline & Frequency & $(\%)$ & Frequency & $(\%)$ & Frequency & $\%$ \\
\hline \multicolumn{7}{|l|}{ Age } \\
\hline $15-17$ & 3 & 2 & 12 & 10 & 15 & 7 \\
\hline $18-25$ & 25 & 20 & 23 & 19 & 48 & 21 \\
\hline $26-39$ & 35 & 28 & 33 & 27 & 68 & 30 \\
\hline$>40$ & 61 & 50 & 53 & 44 & 114 & 51 \\
\hline \multicolumn{7}{|l|}{ Education level } \\
\hline None & 2 & 2 & 5 & 4 & 7 & 3 \\
\hline Elementary & 26 & 21 & 23 & 19 & 49 & 22 \\
\hline High school & 49 & 39 & 73 & 60 & 122 & 54 \\
\hline Diploma Course & 25 & 20 & 11 & 9 & 36 & 16 \\
\hline Undergraduate & 18 & 14 & 8 & 7 & 26 & 12 \\
\hline Postgraduate & 4 & 3 & 1 & 0.8 & 5 & 2 \\
\hline \multicolumn{7}{|l|}{ Residence } \\
\hline Urban & 110 & 89 & 107 & 88 & 217 & 97 \\
\hline Rural & 14 & 11 & 14 & 12 & 28 & 3 \\
\hline \multicolumn{7}{|l|}{ Employed } \\
\hline Yes & 97 & 78 & 85 & 70 & 182 & 81 \\
\hline No & 27 & 22 & 36 & 30 & 63 & 28 \\
\hline \multicolumn{7}{|l|}{ Incomes } \\
\hline$<1 \mathrm{MCLW}^{*}$ & 66 & 53 & 63 & 52 & 129 & 58 \\
\hline 1-2 MCLW & 42 & 34 & 45 & 37 & 87 & 39 \\
\hline >2 MCLW & 15 & 12 & 13 & 11 & 28 & 13 \\
\hline \multicolumn{7}{|c|}{$\begin{array}{l}\text { Familiar with the ecosystems in their } \\
\text { municipalities }\end{array}$} \\
\hline Yes & 106 & 86 & 82 & 68 & 188 & 84 \\
\hline No & 17 & 14 & 38 & 32 & 55 & 25 \\
\hline
\end{tabular}

* 1 Minimum Colombian legal wage = COP 828,116; USD 1 = COP $3356(01 / 24 / 20)$.

\subsection{Monetary Valuation of EcosystemEcosystem Services}

Air purification was an important ES for respondents (mean $=4.7, \mathrm{SD}=0.04$ ). A total of $58 \%$ provided positive responses, in accordance with the WTP, while $42 \%$ stated a negative answer regarding WTP. This indicates that, while most individuals are willing to pay, a high percentage do not agree with the valuation scenario. Regarding the monetary value assigned to the ES, no significant difference was found among those amounts stated in the municipalities $(p=0.8257)$. As for the probability to express a positive WTP, the Logit model, with marginal effects, depicts those variables which influenced responses (Table 3).

Table 3 shows the results of the Logit model, with marginal effects. According to the results of the present investigation, the model was properly specified, in accordance with the errors $(p>0.05)$. It classified $70.83 \%$ of the answers, and in accordance with the HosmerLemeshow test, the model's fit is appropriate $(p>0.05)$. It was found that respondents with higher levels of education and those who formed part of social organizations were more likely to present positive WTPs. Regarding the marginal effects of the Logit model, it was identified that higher schooling levels indicated 33\% more likely to state positive WTPs than those with lower education levels. Additionally, forming part of a social organization contributed to a $25 \%$ higher likelihood to state positive WTPs (Table 3).

On the other hand, the maximum WTP was tested by the Tobit model (Table 4). In this case, the Tobit model produced estimators in accordance with WTP distribution, that is, to measure the social value for a change in the supply of AP. When an explained variable has a natural bias, truncated models balance estimators. The Tobit model showed that those 
under 40 were willing to pay COP 029 less than $>40$-year-old respondents. Additionally, in connection to the non-educational level, those who had been educated through elementary would pay COP 6062, and others would pay COP 12,329 if they had been educated through high school. Finally, forming part of a social organization increased the said contribution by COP 1353 (Table 4).

Table 3. Logit model with marginal effects.

\begin{tabular}{cccccc}
\hline WTP-Yes & Coefficient & S.E. & $\mathbf{z}$ & $p>|\mathbf{z}|$ & dy/dx \\
\hline Gender & 0.367 & 0.346 & 1.060 & 0.289 & 0.3303 \\
Age & -0.068 & 0.338 & -0.200 & 0.841 & -0.0138 \\
Education level & 1.622 & 0.316 & 5.130 & $0.000^{*}$ & 0.3303 \\
Residence & 0.054 & 0.523 & 0.100 & 0.918 & 0.0110 \\
Organización & 1.216 & 0.686 & 1.770 & $0.076^{* *}$ & 0.2476 \\
Knows & 0.418 & 0.386 & 1.080 & 0.280 & 0.0851 \\
Air importance & 0.037 & 0.234 & 0.160 & 0.873 & 0.0076 \\
_cons & -3.571 & 1.365 & -2.620 & 0.009 & \\
\% Classification & & $70.8 \%$ & & & \\
Log likelihood $=$ & & -113.76162 & & & \\
Prob chi ${ }^{2}=$ & 0.0000 & & & \\
Pseudo R ${ }^{2}=$ & 0.1435 & & & \\
R2 McFadden & & 0.144 & & & \\
Roc curve & 0.7536 & & & \\
Hosmer-Lemeshow chi2 $=$ & 0.3297 & & & \\
\hline Sig. & & &
\end{tabular}

Sig. ${ }^{*} p<0.01 ;{ }^{* *} p<0.10$.

Table 4. Tobit (censored).

\begin{tabular}{cc}
\hline WTP & Tobit \\
\hline Gender & -6029.2 \\
Age & $-10,115.2 *$ \\
Education level & 6062.6 \\
Residence & 2551.6 \\
Organization & -1353.0 \\
Knows & -1449.8 \\
Air importance & 4934.2 \\
cons & $-14,967.6$ \\
/sigma & $20,649.9$ \\
\hline Number of obs $=$ & 91 \\
left-censored WTP $\leq 0$ & 1 \\
Log likelihood $=$ & -1022.7472 \\
Prob $>$ chi ${ }^{2}=$ & 0.1302 \\
Pseudo $\mathrm{R}^{2}=$ & 0.0054 \\
Prob $>\mathrm{F}=$ & 0.0037 \\
$\mathrm{R}^{2}=$ & 0.1066 \\
Breusch-Pagan Prob $>$ chi $^{2}=$ & 0.0000 \\
Test White Heteroskedasticity $(p)$ & 0.8064 \\
Ramsey test Prob $>\mathrm{F}=$ & 0.0012 \\
\hline
\end{tabular}
Sig. ${ }^{*} p<0.05$

Finally, in terms of the monthly amount, it was more likely that those from the municipalities were willing to pay a total of $13,784 \mathrm{COP} /$ month. The aggregated value for the entire population, in both municipalities, was $436,277,384 \mathrm{COP} /$ month, or 5,235,328,608 $\mathrm{COP} /$ year (approximately 1.5 million USD/year).

\subsection{Social Valuation}

Regarding the stated hypothesis, no correlation was found between the importance level and the amount they were willing to pay ( $\mathrm{rho}=0.0134, p=0.8350)$. In this sense, regardless of the high importance assigned to AP, there was no correlation with WTP 
values. In this case, higher levels of importance in the ES did not ensure higher payment amounts. It is important to highlight that, correlation does not necessarily mean causation, and thus, the fact that the importance of air as a variable is not causing the WTP is already represented by the insignificant parameter of the Logit model (Table 3). Although this study found conflicted valuation languages, it is important to stress that several value domains can coexist in the same area. This is so because of the instrumental values captured through a WTP, which only expressed utility measurements for respondents, while other values of $\mathrm{AP}$, such as fundamental values (importance for sustaining life) and intrinsic values, were highlighted as non-instrumental relations with nature, as these value domains often express a sense of collective meaning [33].

\section{Discussion}

\subsection{Importance and Monetary Valuation of Air Purification}

Regarding the identification of AP as a priority, the literature emphasizes that AP is a highly valued ES in urban contexts (in terms of social importance level), given its contribution to urban quality of life $[8,17,48]$. Although the research on air quality recognizes the great importance of the value to be paid, few studies assign a specific amount to AP because these values are involved in multiple ES assessment contexts [8,22]. However, regarding the monetary value of $\mathrm{AP}$, per se, a study carried out by [49] identified an amount of $12.27 \mathrm{USD} /$ month, while [50] stressed that air purification was the main reason to pay a total value of $9.90 \mathrm{USD} / \mathrm{month}$ for green urban areas. In contrast, the present study found a total of $13,784 \mathrm{COP} /$ month (USD 4.1), which is a significantly lower amount. One reason that explains the result is related to the high levels of negative WTP $(42 \%)$. Such a high negative WTP means that, even if stakeholders prioritized air purification as a fundamental ES, and respondents rated AP with high values of importance, in general, they did not find "air quality issues" in their municipalities. Additionally, it means that some respondents are "adverse" to the proposed change and should be compensated. Conversely, in highly polluted urban areas, positive WTP reached 78\% [26] even 84\% [25], which demonstrates that AP valuation is context-specific.

Regarding WTP application via the contingent valuation method, it is important to note certain limitations, as highlighted by several authors [51]. Within the context of this investigation, results only showed pathways to the understanding of one scenario, rather than several potential scenarios, regarding environmental trade-offs and WTP particularly, within the context of environmental changes [52]. Hence, it is important to perform further research to deepen the understanding of several WTP aspects, in addition to social valuation implications.

\subsection{Mismatches between Monetary Values and Social Values of Air Purification in the Present Case}

This study shows that, regardless of the high importance assigned to AP, there was no correlation with WTP values. In this case, higher levels of importance in the ES did not ensure higher payment amounts. These results invite a deepening of the plural valuation, defined as a science-policy process that assesses the multiple values attributed to nature by social actors, and the ways in which this knowledge can guide decision making [36].

In this case, study, monetary (instrumental) values did not necessarily reflect the social importance that individuals assigned to ES, for two reasons: first, when stressing the importance of a prioritized ES "in abstraction" (i.e., theoretical importance given to the ES), the societal validation process could fit the importance of ES into a context-specific scenario (e.g., low air quality issues), which confronts social values with monetary values (i.e., not paying a lot for something that is already "good"). Secondly, as highlighted by many researchers, limiting ES valuation to monetary units generates insufficient approaches to ES complexity [48,52-55].

The values that individuals place on ecosystem services have been identified as a critical dimension of the sustainable management of social-ecological systems. In recent times, the call for the integration of plural ecosystem values, beyond just intrinsic and 
instrumental values, has inspired the notion of "relational values" [56]. Plural valuation approaches could be improved by distinguishing relational from instrumental values and by expressing these in nonmonetary terms. The results of the present study argue that multiple ecosystem values expressed by societies should be included in environmental management, so as to tackle social conflicts and consider the diverse needs and interests of different stakeholders.

In agreement with [57], in environmental economics, it is key to seek an adequate balance between disciplinary excellence, interdisciplinary collaboration, and political impact. In [58], the insufficiency of collaboration between economists and other disciplines is clearly demonstrated. With this value pluralism approach, scholars can integrate multiple disciplines, as well as qualitative and quantitative methods in ecosystem service valuation $[37,59,60]$.

In this sense, although it is not always necessary to express the value of ESs in monetary terms, such values may be useful if the outcome delivers information to support decision making, and provide technical support, as well as information [61]. Recognizing the plural values that individuals attribute to ecosystems is a critical research priority toward the sustainable management of ecosystems. Pluralistic valuations may aid in aligning management interventions with individuals' values [30,31], as well as the identification of consensual and conflicting values connected with management approaches [30,31,62]. Therefore, it is strongly recommended to not consider only the 1.5 million USD/year value in the study area but the need to integrate social and monetary values into the perspective of concrete actions aimed to sustain forest areas for AP as well.

Therefore, any conventional method of microeconomic air valuation would lead to imprecise monetary quantifications, due to its classification as a public good without rivalry and excludability. The above implies that perception surveys, despite their basis on assumptions, provide a starting point for indirect assessment, in accordance with the sensitivity of the population and their degree of awareness of the environmental deterioration of air, to implement anthropic factors that communities have identified previously.

Numerous value articulating methods have been applied for ES valuation, from the viewpoint of the beneficiaries' subjective appreciation [63-66]. New developments include the integration of indigenous and local knowledge systems and practices [67], the development of integrative frameworks [68], and the comparative study of methods capacities to capture plural values [33,60]. In order to address these issues, not only is there a need to develop proper assessment methods, but also to disclose the theoretical basics of this assessment, and which trade-offs go hand-in-hand with different assessment types [63-65]. Completely new issues for the valuation of ecosystem services and natural capital arise with the development of new tools.

\section{Conclusions}

Helping ecosystem services' monetary and social values to match is of great interest for both the academic and policy-making communities since this joint analysis would allow for the obtention of a broader understanding of the values of ESs in specific contexts. The present study thus aimed to perform a valuation of the air purification ES from a monetary and social perspective, in order to highlight ES valuation mismatches. Therefore, one conclusion from this investigation is that the economic valuation, expressed in monetary units, does not necessarily reflect the social importance attributed to the AP ecosystem service. It does indicate that, although the monetary value of AP was about 1.5 million USD/year in the study area, the results reflect that the statement "the higher the importance given to AP is, the higher the monetary value will be" was not suitable for the study area. Thus, it is of interest to integrate social and monetary values into the decisionmaking process, in order to encompass the complexity of ES and conciliate mismatches to generate more accurate socio-ecosystem management strategies, or to make decisions considering social perspectives (ES importance) and monetary values, so as to address valuation mismatches. 
The mismatches between economic and social valuations reflected in this case study show that, in order to understand the "integral value" of ecosystem services, it is essential to move toward more pluralistic valuations, which contemplate instrumental values (such as economic valuation), but also sociocultural and intrinsic values. Understanding the ES value in real-life field exercises, such as that presented herein, highlights the immense sociocultural complexity and multiple views of value that stakeholders may have. A final recommendation for future research is undoubtedly to advance to more pluralistic evaluations.

Supplementary Materials: The following are available online at https: / www.mdpi.com/article/ 10.3390/f12091274/s1, Table S1: Main ecological structure in the two municipalities. Table S2: Ecosystem Services identification and prioritization.

Author Contributions: Conceptualization A.S. and C.R.-A.; methodology, A.S. and E.C.-E.; validation, C.R.-A., E.C.-E., G.Y.F.-Y. and L.A.V.-M.; formal analysis, A.S.; investigation, A.S.; resources, A.S.; data curation, A.S. writing-original draft preparation, A.S.; writing-review and editing, C.R.-A., E.C.-E.; G.Y.F.-Y. and L.A.V.-M. All authors have read and agreed to the published version of the manuscript.

Funding: The authors thanks the Corporación Autónoma Regional de Caldas-CORPOCALDAS-for funding project number [222/2019], entitled 'Prospectar la biodiversidad y sus servicios ecosistémicos en la subregión norte del departamento de Caldas, como insumo técnico y jurídico para la determinante de estructura ecológica principal de la subregión Norte.' Furthermore, the authors acknowledge the Wildlife Conservation Society of Colombia for supporting and funding the consultancy process. Special thanks go to the young researchers who helped throughout the fieldwork process. Thanks to F. Gaviria for his support.

Institutional Review Board Statement: The study was conducted according to the guidelines of the Declaration of Helsinki and approved by the Institutional Review Board (or Ethics Committee) of Universidad de la Costa (Acta 88 de 2020).

Informed Consent Statement: Informed consent was obtained from all subjects involved in the study.

Data Availability Statement: Not applicable.

Conflicts of Interest: The authors declare no conflict of interest.

\section{References}

1. Fisher, B.; Turner, R.K.; Morling, P. Defining and classifying ecosystem services for decision making. Ecol. Econ. 2009, 68, 643-653. [CrossRef]

2. Haines-Young, R.; Potschin, M.B. Common International Classification of Ecosystem Services (CICES) V5.1 and Guidance on the Application of the Revised Structure; Fabis Consulting Ltd.: Nottingham, UK, 2018.

3. Maes, J.; Egoh, B.; Willemen, L.; Liquete, C.; Vihervaara, P.; Schägner, J.P.; Grizzetti, B.; Drakou, E.G.; La Notte, A.; Zulian, G.; et al. Mapping ecosystem services for policy support and decision making in the European Union. Ecosyst. Serv. 2012, 1, 31-39. [CrossRef]

4. Kandziora, M.; Burkhard, B.; Müller, F. Interactions of ecosystem properties, ecosystem integrity and ecosystem service indicators: A theoretical matrix exercise. Ecol. Indic. 2013, 28, 54-78. [CrossRef]

5. Wallace, K.J. Classification of ecosystem services: Problems and solutions. Biol. Conserv. 2007, 139, 235-246. [CrossRef]

6. Charles, M.; Ziv, G.; Bohrer, G.; Bakshi, B.R. Connecting air quality regulating ecosystem services with beneficiaries through quantitative serviceshed analysis. Ecosyst. Serv. 2019, 41, 101057. [CrossRef]

7. Escobedo, F.J.; Kroeger, T.; Wagner, J.E. Urban forests and pollution mitigation: Analyzing ecosystem services and disservices. Environ. Pollut. 2011, 159, 2078-2087. [CrossRef] [PubMed]

8. Higuera, D.; Martín-López, B.; Sánchez-Jabba, A. Social preferences towards ecosystem services provided by cloud forests in the neotropics: Implications for conservation strategies. Reg. Environ. Chang. 2012, 13, 861-872. [CrossRef]

9. Thompson, I.; Mackey, B.; McNulty, S.; Mosseler, A. Forest resilience, biodiversity, and climate change. A synthesis of the biodiversity/resilience/stability relationship in forest ecosystems. In Secretariat of the Convention on Biological Diversity; Technical Series No. 43; Secretariat of the Convention on Biological Diversity: Montreal, QC, Canada, 2009.

10. Baró, F.; Calderón-Argelich, A.; Langemeyer, J.; Connolly, J.J. Under one canopy? Assessing the distributional environmental justice implications of street tree benefits in Barcelona. Environ. Sci. Policy 2019, 102, 54-64. [CrossRef] [PubMed]

11. Feng, Z.; Cui, Y.; Zhang, H.; Gao, Y. Assessment of human consumption of ecosystem services in China from 2000 to 2014 based on an ecosystem service footprint model. Ecol. Indic. 2018, 94, 468-481. [CrossRef] 
12. Song, C.; Lee, W.K.; Choi, H.A.; Kim, J.; Jeon, S.W.; Kim, J.S. Spatial assessment of ecosystem functions and services for air purification of forests in South Korea. Environ. Sci. Policy 2016, 63, 27-34. [CrossRef]

13. Baró, F.; Palomo, I.; Zulian, G.; Vizcaino, P.; Haase, D.; Gómez-Baggethun, E. Mapping ecosystem service capacity, flow and demand for landscape and urban planning: A case study in the Barcelona metropolitan region. Land Use Policy 2016, 57, 405-417. [CrossRef]

14. Xing, Y.; Brimblecombe, P. Role of vegetation in deposition and dispersion of air pollution in urban parks. Atmos. Environ. 2018, 201, 73-83. [CrossRef]

15. Yang, S.; Zhao, W.; Pereira, P.; Liu, Y. Socio-cultural valuation of rural and urban perception on ecosystem services and human well-being in Yanhe watershed of China. J. Environ. Manag. 2019, 251, 109615. [CrossRef] [PubMed]

16. Jeanloz, S.; Lizin, S.; Beenaerts, N.; Brouwer, R.; Van Passel, S.; Witters, N. Towards a more structured selection process for attributes and levels in choice experiments: A study in a Belgian protected area. Ecosyst. Serv. 2016, 18, 45-57. [CrossRef]

17. Zhang, H.; Pang, Q.; Long, H.; Zhu, H.; Gao, X.; Li, X.; Jiang, X.; Liu, K. Local Residents' Perceptions for Ecosystem Services: A Case Study of Fenghe River Watershed. Int. J. Environ. Res. Public Health 2019, 16, 3602. [CrossRef]

18. Baró, F.; Haase, D.; Gómez-Baggethun, E.; Frantzeskaki, N. Mismatches between ecosystem services supply and demand in urban areas: A quantitative assessment in five European cities. Ecol. Indic. 2015, 55, 146-158. [CrossRef]

19. Kibria, A.S.; Behie, A.; Costanza, R.; Groves, C.; Farrell, T. The value of ecosystem services obtained from the protected forest of Cambodia: The case of Veun Sai-Siem Pang National Park. Ecosyst. Serv. 2017, 26, 27-36. [CrossRef]

20. Lee, H.J.; Yoo, S.H.; Huh, S.Y. Economic benefits of introducing LNG-fuelled ships for imported flour in South Korea. Transp. Res. Part D Transp. Environ. 2020, 78, 102220. [CrossRef]

21. Shannon, A.K.; Usmani, F.; Pattanayak, S.K.; Jeuland, M. The Price of Purity: Willingness to pay for air and water purification technologies in Rajasthan, India. Environ. Resour. Econ. 2018, 73, 1073-1100. [CrossRef]

22. Li, T.; Gao, X. Ecosystem services valuation of lakeside wetland park beside Chaohu Lake in China. Water 2016, 8, 301. [CrossRef]

23. Pérez-Sánchez, D.; Montes, M.; Cardona-Almeida, C.; Vargas-Marín Luís, A.; Enríquez-Acevedo, T.; Suarez, A. Keeping people in the loop: Socioeconomic valuation of dry forest ecosystem services in the Colombian Caribbean region. J. Arid Environ. 2021, 188, 104446. [CrossRef]

24. Freeman, R.; Liang, W.; Song, R.; Timmins, C. Willingness to pay for clean air in China. J. Environ. Econ. Manag. 2019, 94, 188-216. [CrossRef]

25. Pu, S.; Shao, Z.; Yang, L.; Liu, R.; Bi, J.; Ma, Z. How much will the Chinese public pay for air pollution mitigation? A nationwide empirical study based on a willingness-to-pay scenario and air purifier costs. J. Clean. Prod. 2019, 218, 51-60. [CrossRef]

26. Wang, B.; Hong, G.; Qin, T.; Fan, W.R.; Yuan, X.C. Factors governing the willingness to pay for air pollution treatment: A case study in the Beijing-Tianjin-Hebei region. J. Clean. Prod. 2019, 235, 1304-1314. [CrossRef]

27. Yao, L.; Deng, J.; Johnston, R.J.; Khan, I.; Zhao, M. Evaluating willingness to pay for the temporal distribution of different air quality improvements: Is China's clean air target adequate to ensure welfare maximization? Can. J. Agric. Econ. 2019, 67, 215-232. [CrossRef]

28. Ligus, M. Measuring the Willingness to Pay for Improved Air Quality: A Contingent Valuation Survey. Pol. J. Environ. Stud. 2018, 27, 763-771. [CrossRef]

29. Soo, J.S.T. Valuing Air Quality in Indonesia Using Households' Locational Choices. Environ. Environ. Resour. Econ. 2017, 71, 755-776.

30. Ives, C.D.; Kendal, D. The role of social values in the management of ecological systems. J. Environ. Manag. 2014, 144, 67-72. [CrossRef]

31. Jones, N.A.; Shaw, S.; Ross, H.; Witt, K. Pinner, B. The study of human values in understanding and managing socialecological systems. Ecol. Soc. 2016, 21, 15. [CrossRef]

32. Pascual, U.; Balvanera, P.; Díaz, S.; Pataki, G.; Roth, E.; Stenseke, M.; Watson, R.T.; Dessane, E.B.; Islar, M.; Kelemen, E.; et al. Valuing nature's contributions to people: The IPBES approach. Curr. Opin. Environ. Sustain. 2017, 26-27, 7-16. [CrossRef]

33. Arias-Arévalo, P.; Gómez-Baggethun, E.; Martín-López, B.; Pérez-Rincón, M. Widening the evaluative space for ecosystem services: A taxonomy of plural values and valuation methods. Environ. Values 2018, 27, 29-53. [CrossRef]

34. Gómez-Baggethun, E.; Martín-López, B. Ecological economics perspectives on ecosystem services valuation. In Handbook of Ecological Economics; Martínez-Alier, J., Muradian, R., Eds.; Edward Elgar: Cheltenham, UK, 2019; pp. $260-282$.

35. Jacobs, S.; Zafra-Calvo, N.; Gonzalez-Jimenez, D.; Guibrunet, L.; Benessaiah, K.; Berghöfer, A.; Chaves-Chaparro, J.; Díaz, S.; Gomez-Baggethun, E.; Lele, S.; et al. Use your power for good: Plural valuation of nature-The Oaxaca statement. Glob. Sustain. 2020, 3, e8. [CrossRef]

36. Kenter, J.O. Editorial: Shared, plural and cultural values. Ecosyst. Serv. 2016, 21, 175-183. [CrossRef]

37. Livia, W.P.; Pérez, J.J. Valoración económica de la calidad de aire y su impacto en registros epoc de Bucaramanga. Aibi Rev. Investig. Adm. Ing. 2014, 2, 13-18. [CrossRef]

38. Vieira, J.; Matos, P.; Mexia, T.; Silva, P.; Lopes, N.; Freitas, C.; Correia, O.; Santos-Reis, M.; Branquinho, C.; Pinho, P. Green spaces are not all the same for the provision of air purification and climate regulation services: The case of urban parks. Environ. Res. 2018, 160, 306-313. [CrossRef] 
39. Pascual, U.; Muradian, R.; Brander, L.; Gómez-Baggethun, E.; Martín-López, B.; Verma, M.; Armsworth, P.; Christie, M.; Cornelissen, H.; Eppink, F.; et al. Chapter 5. The economics of valuing ecosystem services and biodiversity. In The Economics of Ecosystems and Biodiversity. Ecological and Economic Foundations; 2010. Available online: http://africa.teebweb.org/wpcontent/uploads/2013/04/D0-Chapter-5-The-economics-of-valuing-ecosystem-services-and-biodiversity.pdf (accessed on 13 October 2020).

40. Pearce, D.; Atkinson, G.; Mourato, S. Cost-Benefit Analysis and the Environment: Recent Developments; Organisation for Economic CoOperation and Development. Available online: https:/ / www.oecd.org/governance/cost-benefit-analysis-and-the-environment9789264085169-en.htm (accessed on 29 June 2020).

41. Da Motta, R.S.; Ortiz, R.A. Costs and Perceptions Conditioning Willingness to Accept Payments for Ecosystem Services in a Brazilian Case. Ecol. Econ. 2018, 147, 333-342. [CrossRef]

42. Chu, X.; Zhan, J.; Wang, C.; Hameeda, S.; Wang, X. Households' Willingness to Accept Improved Ecosystem Services and Influencing Factors: Application of Contingent Valuation Method in Bashang Plateau, Hebei Province, China. J. Environ. Manag. 2020, 255, 109925. [CrossRef] [PubMed]

43. Abdullah, S.; Jeanty, P.W. Willingness to pay for renewable energy: Evidence from a contingent valuation survey in Kenya. Renew. Sustain. Energy Rev. 2011, 15, 2974-2983. [CrossRef]

44. SIRAP Eje Cafetero. Clasificación de Ecosistemas Naturales Terrestres del eje Cafetero. 2013. Available online: https://www.wwf. org.co/?213162/Clasificacion-de-Ecosistemas-Naturales-Terrestres-del-Eje-Cafetero (accessed on 12 December 2020).

45. Maskey, B.; Singh, M. Households' willingness to pay for improved waste collection service in Gorkha municipality of Nepal. Environments 2017, 4, 77. Available online: https:/ / www.mdpi.com/2076--3298/4/4/77 (accessed on 23 April 2021). [CrossRef]

46. Johnston, R.J.; Boyle, K.J.; Adamowicz, W.; Bennett, J.; Brouwer, R.; Cameron, T.A.; Hanemann, W.M.; Hanley, N.; Ryan, M.; Scarpa, R.; et al. Contemporary guidance for stated preference studies. J. Assoc. Environ. Resour. Econ. 2017, 4, 319-405. [CrossRef]

47. Loomis, J.B. WAEA keynote address: Strategies for overcoming hypothetical bias in stated preference surveys. J. Agric. Resour. Econ. 2014, 39, 34-46.

48. Martín-López, B.; Iniesta-Arandia, I.; García-Llorente, M.; Palomo, I.; Casado-Arzuaga, I.; Del Amo, D.G.; Gómez-Baggethun, E.; Otero-Rozas, E.; Palacios-Agundez, I.; Willaarts, B.; et al. Uncovering ecosystem service bundles through social preferences. PLoS ONE 2012, 7, e38970. [CrossRef]

49. Kennedy, E. Comparing Valuation Methods for Ecosystem Services in Amstelland. Applying Ecosystem Service Valuation Methods to Evaluate Land-Use Changes. Bachelor's Thesis, Vrije University Amsterdam, 2014. Available online: https://spinlab.vu.nl/wp-content/uploads/2016/09/Comparing_valuation_methods_for_ecosystem_services_in_ Amstelland_BSCThesis_Eric_Kennedy_thesis.pdf (accessed on 24 January 2021).

50. Lo, A.Y.; Jim, C.Y. Willingness of residents to pay and motives for conservation of urban green spaces in the compact city of Hong Kong. Urban For. Urban Green. 2010, 9, 113-120. [CrossRef]

51. Logar, I.; van den Bergh, J.C. Respondent uncertainty in contingent valuation of preventing beach erosion: An analysis with a polychotomous choice question. J. Environ. Manag. 2012, 113, 184-193. [CrossRef] [PubMed]

52. Enriquez-Acevedo, T.; Botero, C.M.; Cantero-Rodelo, R.; Pertuz, A.; Suarez, A. Willingness to pay for Beach Ecosystem Services: The case study of three Colombian beaches. Ocean Coast. Manag. 2018, 161, 96-104. [CrossRef]

53. Stephenson, K.; Shabman, L. Does ecosystem valuation contribute to ecosystem decision making? Evidence from hydropower licensing. Ecol. Econ. 2019, 163, 1-8. [CrossRef]

54. Gómez-Baggethun, E.; Ruiz-Pérez, M. Economic valuation and the commodification of ecosystem services. Prog. Phys. Geogr. Earth Environ. 2011, 35, 613-628. [CrossRef]

55. Liu, S.; Costanza, R.; Farber, S.; Troy, A. Valuing ecosystem services. Theory practice, and need for transdisciplinary synthesis. Ann. N. Y. Acad. Sci. 2010, 1185, 54-78. [CrossRef]

56. Arias-Arévalo, P.; Martín-López, B.; Gómez-Baggethun, E. Exploring intrinsic, instrumental, and relational values for sustainable management of social-ecological systems. Ecol. Soc. 2017, 22, 43. [CrossRef]

57. Bretschger, L.; Pittel, K. Twenty Key Challenges in Environmental and Resource. Environ. Resour. Econ. 2020, 77, 725-750. [CrossRef]

58. Polasky, S.C.L.; Kling, S.A.; Levin, S.R.; Carpenter, G.C.; Daily, P.R.; Ehrlich, G.M.; Heal; Lubchenco, J.; Strassheim, H.; Beck, S. Handbook of Behavioural Change and Public Policy; Handbooks of Research on Public Policy Series; Edward Elgar: Cheltenham, UK, 2019.

59. Tadaki, M.; Sinner, J.; Chan, K.M.A. Making sense of environmental values: A typology of concepts. Ecol. Soc. 2017, 22, 7. [CrossRef]

60. Jacobs, S.; Martin-Lopez, B.; Barton, D.N.; Dunford, R.; Harrison, P.A.; Kelemen, E.; Saarikoski, H.; Termansen, M.; GarcíaLlorente, M.; Gómez-Baggethun, E.; et al. The means determine the end-Pursuing integrated valuation in practice. Ecosyst. Serv. 2018, 29, 515-528. [CrossRef]

61. Laurans, Y.; Rankovic, A.; Billé, R.; Pirard, R.; Mermet, L. Use of ecosystem services economic valuation for decision making: Questioning a literature blindspot. J. Environ. Manag. 2013, 119, 208-219. [CrossRef]

62. Jacobs, S.; Dendoncker, N.; Martin-Lopez, B.; Barton, D.N.; Gomez-Baggethun, E.; Boeraeve, F.; McGrath, F.L.; Vierikko, K.; Geneletti, D.; Sevecke, K.J.; et al. A new valuation school: Integrating diverse values of nature in resource and land use decisions. Ecosyst. Serv. 2016, 22, 213-220. [CrossRef] 
63. Brei, M.; Pérez-Barahona, A.; Strobl, E. Protecting species through legislation: The case of sea turtles. Am. J. Agric. Econ. 2020, 102, 300-328. [CrossRef]

64. Antoci, A.; Borghesi, S.; Russu, P. Don't feed the bears! Environmental defense expenditures and species-typical behaviour in an optimal growth model. Macroecon. Dyn. 2019, 25, 733-752. [CrossRef]

65. Drupp, M.A. Limits to substitution between ecosystem services and manufactured goods and implications for social discounting. Environ. Resour. Econ. 2018, 69, 135-158. [CrossRef]

66. Enríquez-Acevedo, T.; Pérez-Torres, J.; Ruiz-Agudelo, C.; Suarez, A. Seed dispersal by fruit bats in Colombia generates ecosystem services. Agron. Sustain. Dev. 2021, 40,1-15. [CrossRef]

67. Tengö, M.; Brondizio, E.S.; Elmqvist, T.; Malmer, P.; Spierenburg, M. Connecting diverse knowledge systems for enhanced ecosystem governance: The multiple evidence base approach. Ambio 2014, 43, 579-591. [CrossRef] [PubMed]

68. Hill, R.; Breslow, S.; Le Buhn, G.; Quezada-Euánn, J.J.; Kwapong, P.; Nates-Parra, G.; Buchori, D.; Howlett, B.; Maués, M.M.; Saeed, S.; et al. Biocultural diversity, pollinators and their socio-cultural values. In The Assessment Report of the Intergovernmental Science-Policy Platform on Biodiversity and Ecosystem Services on Pollinators, Pollination and Food Production; Secretariat of the Intergovernmental Science-Policy Platform on Biodiversity and Ecosystem Services; Potts, S.G., Imperatriz-Fonseca, V.L., Ngo, H.T., Eds.; 2016; pp. 276-359. Available online: https:/ / ainfo.cnptia.embrapa.br/digital/bitstream/item/157539/1/Chapter5 -Pollination-Published.pdf (accessed on 16 September 2021). 